\title{
The Relationship between Economic Value Added with Liquidity and Returns in Companies Listed in Tehran Stock Exchange
}

\author{
Isa Bakhtyari Mansourabad
}

Department of Accounting, College of Graduate Studies, Science and Research Branch of Kohgiluyeh and Boyer-Ahmad, Islamic Azad University, Yasouj, Iran

Received: 24 October 2018, Revised: 05 December 2018, Accepted: 20 December 2018

\begin{abstract}
Economic Value Added is one of the most useful measures for managers' performance evaluation. Another economical criterion used for distinguishing between company's market value and invested capital in the company is market value added. In this paper, it has been tried to study the relationship between economic value added with liquidity and returns of listed companies in Tehran Stock Exchange. For this purpose, we have a sample of 510 companies which have been present in exchange market during the years of 20052010. The companies selected for our sample are those whose financial statements are available for the mentioned period, their fiscal year hasn't been changed during the above mentioned period, and the end of their fiscal year is the same, i.e. the last month of each year in Iran and their stock have been traded during the mentioned years. With application of the above mentioned conditions, the number of research sample reduces to 98 companies. Liquidity and returns are dependent research variables, economic value added is independent variable and controlled variables include company size and the ratio of book value to market value of equity. In this paper, the regression model has been used. The results of the research indicate that there is a positive and significant relationship between economic added value and stock liquidity. Also there is a significant and positive relationship between economic added value and returns. Finally, the results indicate that there is a significant difference in the relationship between economic added value with liquidity in listed companies in Tehran Stock Exchange and returns.
\end{abstract}

Keywords: Economic Added Value, Liquidity, Returns, Tehran Stock Exchange.

\section{Introduction}

The managers of takeover companies, recognize takeover as the fastest way for acquiring growth, acquiring new markets, entering global trading zone, increasing profit and creating economic added value.
On the other hand, there is another view based on negative effect of companies' takeover on the wealth of the shareholders of purchasing companies and the companies which have been taken over. 
The opponents of this belief believe that growth through internal development (starting new projects and newly established companies) is more desirable comparing to purchasing active companies and due to the conducted studies, they claim that most of takeovers and merging companies, after takeover, faces some kind of decrease in the performance from the point of view of financial indicators. One of the motivations and reasons that encourages companies' top managers to adopt takeover and merging strategies is economic added value (Piqueira, 2006).

Stock return volatility is one of the controversial financial topics which has attracted the attention of capital market researchers in new emerging markets (KielGeoffrey et al., 2003). The reason of this inclination goes back to the relationship between price volatility and in turn on return and its effect on the financial section performance as well as the whole economy. On the other hand, the usefulness of stock return volatility on the side of investors is due to the fact that they consider stock return volatility as a risk criterion and also strategy makers of capital market can use this criterion as a means for measuring vulnerability rate of stock market (Yang, 2006).

On the other hand, liquidity is one of the desirable characteristics of competitive markets. Liquidity is defined as the possibility of performing deals in a fast manner with small expenses and without severely affecting the price and has been named as the main determinant of the possibility of markets' survival. This phenomenon in future markets is also the source of durability and an important indicator for studying efficiency and maturity of these markets (Rarvenscraft and Scherer, 1978). On one hand, stock return is one of the most important and complicated concepts which is affected by a variety of factors. Stock return is affected by factors including changes in economic, political, cultural, and social conditions, sentiment reactions in purchasing stock, risk, assets return and especially financial statements items and information provided by them and so many other factors. Today, analysis of accounting variables is a powerful technique and a proper instrument for investors toward a far better recognition and evaluation of past and present performance as well as prediction of future performance and return.

Also, since the time of Adam Smith, the predominant view regarding organizations is that they derive their forces from investors, employees and suppliers to produce and provide their products and services to their customers. In this view, organizational performance refers to the financial return which is received by shareholders (Deuskar, 2006). Therefore, the importance of stock return prediction has make scholars to try to find the variables and indicators which have a significant relationship with stock return as well as the variables which are influential on this relationship. They have always tried to find the influential variables on returns and base their decisions making on them. The obtained results from studies in this field indicate that financial and non-financial information both have effect on stock return (Mehrani et al., 2004).

Understanding the mechanism of Tehran Stock Exchange from different aspects and angels can reduce the risk of investment and in the meantime can predict the future of the market and its changes in a better way. Stock return is one of the most important factors in selecting the best investment. Investors, in addition to considering so many company internal and external financial and non- 
financial factors for prediction and decision making, with awareness of effective factors on stock return, can determine stock price behavior with more accuracy and a better quality and, as a result, can make more effective decisions. Hence, one of the criteria for organization's performance evaluation in this study is stock return.

\section{Research background}

Normally, the works which are studying the information content of variables make their assumption on complete reflection of accounting information and then study the connection between liquidity and stock return. Most of the previously conducted studies indicate a relationship between economic added value and stock return and in this section we will review some of these works.

Austin (2006), in his work, has studied the economic added value as an indicator of performance evaluation of New Zealand Airlines during the years 1995-2003. The findings of his study indicate that economic added value is used as an indicator for pricing the company products (Aitken and Comerton Forde, 2003). Piqueira (2005) believes that trading activities can describe expected return changes in a cross-sectional manner. Evidences of this study indicate the existence of a relationship between the expenses of illiquidity and the size of the company. Also, the effect of the stock of large companies with high liquidity on trade volume is significant. In this study, he introduces trading activities as the only indicator of liquidity (Piqueira, 2006).

Marshal and Yang in 2006 have studied the relationship between normal stock return in Australian market and factors such as Beta risk and the size of company, price offer to buy and sell, flow rate and ratio of illiquidity and their findings indicate that among different indicators of illiquidity, the ratio proposed by Amihood justifies surplus of stock returns better (Marshal and Martin, 2006). Marcello and Quiros in 2006 have studied the illiquidity risk factor in Spain Stock Market during 1994-2002. In this study, they have used the control factor of size and ratio of book value to market value as the illiquidity indicator proposed by Amihood (2002). The findings of this study indicate that illiquidity factor should be considered as one of the key elements of assets pricing (Marcello and Quiros, 2006).

Deuskar (2006) have proposed a model for liquidity behavior and stock price volatility. In this model, the investors predict the recent price changes for the changes of an asset with risk. When the asset changes are high, the risk premium of it will be high and the current return of the asset will be low, the return rate of assets with risk will be also low and market will face illiquidity (Deuskar, 2006). Due to the conducted studies in Iran, also, Yazyazadeh and Khoramdin (2008), have studied "the role of liquidity factors and illiquidity risk on stock return surplus in stock exchange". In this study, due to the importance of the relationship between risk and return, the effect of illiquidity risk and liquidity factors includes market return surplus, company size and ratio of book value to market value on stock return surplus. In this study, the time series model for a time period of Farvardin of 1999 to Esfand of 2005 have been used in monthly manner in Tehran Stock Exchange that includes all the existing companies in Stock Exchange that their stock have been traded at least 100 days during at least a time span of 9 month in exchange market. Also, for reducing the correlation between these variables, portfolio formation method has been used. The findings of this study indicate that all 4-folds independent 
variables have significant effect on research dependent variable. It means that the effect of illiquidity and company size on stock return surplus is negative while the effect of market return surplus and ratio of book value and market value on stock return surplus is positive (Yahyazadeh and Khoramdin, 2008).

Mahdavi and Goyandeh (2009) have studied the relationship between economic added value and refined economic added value with stock return. The main aim of this paper has been studying the relationship between economic added value and refined economic added value with stock return in companies listed in Tehran Stock Exchange. In line with this aim, with the use of combined data, company and year 71 companies listed in Tehran Stock Exchange during the past 10 years have been tested. The research hypotheses have been tested with the use of Pearson's correlation coefficient. The result of the research indicates that there is no significant relationship between economic added value and refined economic added value with stock return (Mahdavi and Goyandeh, 2009).

Darabi and Esfandyari (2009) have studied "the relationship between adjusted economic added value, profit prior to interest and tax deduction and cash flow of operational activities with stock market value of food industry companies listed in Tehran Stock Exchange". The aim of this paper is to study the amount of correlation of adjusted economic added value with stock market value of companies and have compared it with the correlation amount of two more important accounting indicators namely profit prior to interest and tax deduction and operational activities cash flow with stock market value of companies. In other words, whether adjusted economic added value comparing to two other indicators have the capability to better describe the stock market value of companies? In order to answer this question, companies active in food industry listed in Tehran Stock Exchange have been considered and required statistical tests have been conducted. The findings of the study indicate that at the confidence level of $95 \%$ it can be claimed that adjusted economic added value and operational cash flows show similar correlation with market value. It is while the profit prior to deduction of interest and tax comparing to two other indicators have a bigger correlation with stock market value (Darabi and Esfandyari, 2009).

Hasas yeganeh and Delkhoush (2009) in a paper have studied "the relationship between economic added value with dividend per share and stock price in companies listed in Stock Exchange". The focus of attention of economic added value as one of the indicators of performance measurement is on topics such as capital cost and created value for shareholders. One of the basic principles in economic added value concept is that managers are responsible for creating value and maximizing the wealth of shareholders. Hence we can use economic added value as an indicator for measurement of manager's commitment and efficiency and in fact the economic added value pattern is capable to give this answer to shareholders that how much management is involved in increasing their wealth. Since we can measure the company's economic profit correctly with economic added value indicator, therefore, it can be a proper indicator for measuring the company's operational efficiency and we can estimate the effect of management decisions on stock price and company's dividends with it. Therefore, in this paper, we have studied the relationship between 
cash return and stock price with economic added value in companies listed in Stock Exchange during 2000 to 2004. The findings of the study indicate that there is no significant relationship between economic added value and dividends, while a significant relationship have been observed between economic added value and stock price. Therefore, economic added value can be a better estimator for stock price (Hasas Yeganeh and Delkhoush, 2009).

\section{Research hypotheses}

There is a significant and positive relationship between economic added value and liquidity of companies listed in Tehran Stock Exchange.

There is a positive and significant between economic added value and stock return.

There is a significant difference in the relationship between economic added value with stock liquidity of companies listed in Tehran Stock Exchange and stock return.

\section{Research population and sample}

The research population includes all the companies listed in Tehran Stock Exchange with 510 companies which have been present in exchange market during 2005 to 2010 with the conditions that their financial statements will be available, their fiscal year hasn't been changed during these years and their fiscal year end will be in the end of the month of Esfand of each year and their stock have been traded during the mentioned years. The application of the above mentioned conditions the number of companies is reduced to 98 companies.

From all the qualified companies based on the above stated criteria, 98 companies have been selected during 5 years. The sampling method is all and all of these 98 companies are considered as sample.

\section{Research variables and their measurement method}

In this research, we are seeking to study the relationship between economic added value with liquidity and stock return; and for this purpose, we are using both kinds of dependent and independent variables which will be both described below.

A. Dependent variable

Dependent variables of this research are:

1) Liquidity

In this research, in compliance with various studies such as Marshal (2006), Marcellor and Quiros, 254-267), Chan and Faaf (2003), (Bortolotti et al., 2006), Baker and Austin (2003) and Austin (2006), we have used flow rate indicator as stock liquidity indicator. Flow rate indicator is calculated as the ratio of trade's volume to the number of outstanding shares:

Liquidity $=\mathrm{V} / \mathrm{N}$

Where $\mathrm{V}$ refers to trade's volumes and $\mathrm{N}$ refers to the number of company's share.

2) Stock return

The $2^{\text {nd }}$ dependent variable in this study is stock return which is calculated as per the following:

$$
\frac{p_{t}(1+\alpha+\beta)-\left(p_{t-1}+c \alpha\right)+D}{p_{t-1}+c \alpha}
$$

Where $\mathrm{P}_{\mathrm{t}}$ and $\mathrm{P}_{\mathrm{t}-1}$ is stock price at the end and beginning of period of $\alpha, t$ is capital increase percentage from receivables and cash, $\beta$ is the percentage of capital increase from reserve, $c$ is price of new shares underwriting and $\mathrm{D}$ is dividends in the period of $t$.

B. Independent variables

The research main independent variable is economic added value and the calculation method of it as per the following:

E.V.A = (Rate of return on capital -Rate of weighted average cost of capital) * capital employed 
C) Controlled variables

In this research, for a better specification of the model, we have used controlled variables of company size (SIZE) and ratio of book value to market value of shareholders (BTM). The company size is measured with the use of natural sales logarithm.

The used models for hypothesis test and analysis:

A) Secondary research hypothesis 1

For testing this hypothesis we have used regression model:

Liquidityit $=\beta 1+\beta 2$ E.V.Ait $+\beta 3$ SIZEit + $\beta 4$ BTMit $+\varepsilon$ it

Liquidityit: stock liquidity indicator of $\mathrm{i}$ company in the period of $t$

E.V.Ait: economic added value of $i$ company in the period of $t$

SIZEit: size of $i$ company in the period of $t$

BTMit: ratio of book value to market value of $i$ company in the period of $t$

B) Secondary research hypothesis 2

For testing this hypothesis regression model has been used:

Rit $=\beta 1+\beta 2$ E.V.Ait $+\beta 3$ SIZEit $+\beta 4$ BTMit + cit

Rit: stock return of i company in t period

E.V.Ait: economic added value of $i$ company in the period of $t$

SIZEit: size of $i$ company in the period of $t$ BTMit: ratio of book value to market value of Company

\section{Research Methodology}

In this research, statistical tests regarding the possibility of using regression model, correlation between variables, hypotheses test, significance of the regression and significance of coefficient have been used.

Pearson correlation coefficient $(r)$ is a parametric method which is used for data with normal distribution or with large number and the coefficient is calculated with the following equation:

$$
r=\frac{\sum x y-n \overline{x y}}{\sqrt{\sum x^{2}-n \bar{x}^{2}} \sqrt{\sum y^{2}-n \bar{y}^{2}}}
$$

Spearman correlation coefficient (rs), when the number of data is small or when the assumption of data normality is not reasonable another correlation coefficient is used which is not based on main values and is calculated with the following equation and based on data ranks:

$$
r_{s}=1-\frac{6\left(\sum x_{i}^{2}\right)}{\left.n\left(n^{2}-1\right)\right)}
$$

The significance concept in correlation refers to whether the obtained correlation among two variables can be considered random or it really indicates that a correlation exists between them. This is done with the use of t-statistics with the following assumptions:

Ho: $\rho \mathrm{i}=0$ : there is no significant correlation.

$\mathrm{H} 1: \rho 1 \neq 0$ : there is significant correlation. If the calculated t-statistics from regression equation is smaller than the obtained $\mathrm{t}$ from the table at the confidence level of $95 \%$ (error of $\alpha=\% 5$ ), the assumption of $\mathrm{HO}$ will be confirmed and otherwise it is rejected. It is obvious that in case of rejection of $\mathrm{H} 0$, a significant correlation exists.

A multiple regression has different methods. The difference between its methods is in the way of selecting predicting variables.

In this paper, the following equation have been used for determining the regression:

$$
Y=a+b_{1} x_{\uparrow}+b_{r} x_{r}+\cdots+b_{n} x_{n}+u_{t}
$$

Y: ratio of profit to first market value of the period

a: Intercept

$\mathrm{x}_{1}, \mathrm{X}_{2}, \ldots, \mathrm{x}_{\mathrm{n}}$ : all the variables used in this paper

$b_{1}, b_{2}, \ldots, b_{n}$ : obtained regression coefficients of all the variables in this paper 
$\mathrm{ut}_{\mathrm{t}}$ :error phrases

Wald statistics:

For testing the research's main hypothesis, first, the regression models (1) and (2) are fitted and with the use of $t$ student statistics, significance of the relationship between economic added value with variables of stock liquidity and stock return is tested (secondary research hypotheses 1 and 2).

In the next stage, the Wald statistics test is used in order to test the significant difference of the relationship of economic added value with stock liquidity and stock return (main hypothesis). The $\mathrm{z}$ statistics value of this test is obtained by the following equation:

$$
\mathrm{Z}=\frac{\left(\beta_{\uparrow}^{\Upsilon}-\beta_{\uparrow}^{\Upsilon}\right)}{\sqrt{\mathrm{SE}_{\uparrow}^{\Upsilon}+\mathrm{SE}_{\uparrow}^{\Upsilon}}}
$$

Where $\beta$ is the coefficient of economic added value variable in regression models (1) and (2) and SE is standard error of compared models. With comparing the obtained statistics and statistics critical value in normal standard table, the significance of the difference of economic added value relationship with liquidity and stock return is tested.

\section{Data Analysis}

Testing secondary hypothesis 1

In this study, for testing the research secondary hypothesis 1 (relationship between economic added value with stock liquidity), the below multi-regression model has been fitted:

(1) $\quad$ Liquidityit $=\beta 1+\beta 2$ E.V.Ait $+\beta 3$ SIZEit $+\beta 4$ BTMit $+\varepsilon i t$

Table 1. Obtained Results from Fitting Regression Equation (1)

\begin{tabular}{|c|c|c|c|c|}
\hline \multicolumn{5}{|c|}{ (1) Liquidity $_{i t}=\beta_{1}+\beta_{2}$ E.V.A $_{i t}+\beta_{3}$ SIZE $_{i t}+\beta_{4}$ BTM $_{i t}+\varepsilon_{i t}$} \\
\hline Variable name & $\begin{array}{l}\text { Variable } \\
\text { symbol }\end{array}$ & $\begin{array}{l}\text { Variable } \\
\text { coefficient }\end{array}$ & t statistics & $\begin{array}{c}\text { Significance } \\
\text { levle }\end{array}$ \\
\hline Constant value & Constant & 1.12 & 5.5074 & .000 \\
\hline Economic added value & E.V.A $A_{i t}$ & 0.365 & 2.108 & 0.036 \\
\hline Company size & $\mathrm{SIZE}_{\mathrm{it}}$ & 0.248 & 2.871 & 0.004 \\
\hline $\begin{array}{l}\text { Ratio of book value to } \\
\text { market value of equity }\end{array}$ & BTM $_{\text {it }}$ & -0.125 & 2.63276 & 0.0086 \\
\hline Determining coefficient & 0.444 & \multicolumn{2}{|c|}{ F statistics } & 13.418 \\
\hline $\begin{array}{l}\text { Adjusted determining } \\
\text { coefficient }\end{array}$ & 0.411 & \multicolumn{2}{|c|}{ Significance of ( $\mathrm{p}$-value) } & .00 \\
\hline & & \multicolumn{2}{|c|}{ Durbin Watson statistics } & 1.789 \\
\hline
\end{tabular}

As it is shown in Table 1, determining coefficient is $44.4 \%$ and adjusted determining coefficient is $41.1 \%$. The reason of using adjusted determining coefficient is that, with adding the number of independent variables to regression model, it is possible that the value of $\mathrm{R}^{2}$ will be increased. For preventing this and controlling inflation of $\mathrm{R}^{2}, \mathrm{R}^{2}$ adjusted statistics is used which solves the $\mathrm{R}^{2}$ problems. The high value of adjusted determining coefficient (0.411) of fitted regression indicates the high descriptive power of the model.

As per Table 1, the significance level of economic added value variable is equal to 0.036, which is smaller than the determined significance level in the current study (5\%); on the other hand, the absolute value of $t$ statistics relating to this variable $|2 / 108|$ is bigger than the obtained $\mathrm{t}$ statistics from the table with the same 
freedom degree (1.96). Therefore, this variable is significant in the fitted regression of model (1) and we can use the estimated coefficient for it. The significance level of the variable of company size is equal to 0.004 , which is less that the determined significance level for the current study (5\%); also the absolute value of the $t$ statistics related to this variable 12.8711 is bigger than the obtained t statistics from the table with the same freedom degree (1.96). In addition, the variable of the ratio of book value to market value of equity has a smaller significance level comparing to the one determined for this study 0.0086 against 0.05 ) and, on the other hand, the absolute value of the $t$ statistics related to this variable 12.6327l is bigger than the obtained t statistics from the table with the same freedom degree (1.96), and therefore, this variable is also significant and we can use the estimated coefficient for it.
In general, the results of Table 1 indicate that at the confidence level of $95 \%$ the variables of economic added value and company size have a positive and significant relationship with stock liquidity and the variable of the ratio of book value to market value of equity has a negative and significant relationship with stock liquidity. Therefore, hypothesis 1 of the study indicating a positive and significant relationship between economic added value and stock liquidity is confirmed.

Testing secondary hypothesis 2

In this study, for testing the research secondary hypothesis 2 (relationship between economic added value with stock return) the below multi-regression model has been fitted:

(2) $\quad$ Rit $=\beta 1+\beta 2$ E.V.Ait $+\beta 3$ SIZEit $+\beta 4$ BTMit

Table 2 presents the obtained results from fitting the above regression model.

Table 2. Obtained Results from Fitting Regression Equation (2)

\begin{tabular}{|c|c|c|c|c|}
\hline \multicolumn{5}{|c|}{ (2) $R_{i t}=\beta_{1}+\beta_{2}$ E.V.A.A $A_{i t}+\beta_{3}$ SIZE $_{i t}+\beta_{4}$ BTM $_{i t+} \varepsilon_{i t}$} \\
\hline Variable name & $\begin{array}{l}\text { Variable } \\
\text { symbol }\end{array}$ & $\begin{array}{l}\text { Variable } \\
\text { coefficient }\end{array}$ & t statistics & $\begin{array}{l}\text { Significance } \\
\text { levle }\end{array}$ \\
\hline Constant value & Constant & 0.621 & 8.127 & .000 \\
\hline Economic added value & E.V.A $A_{i t}$ & 0.471 & 2.843 & 0.005 \\
\hline Company size & $\mathrm{SIZE}_{\mathrm{it}}$ & 0.367 & -2.619 & 0.009 \\
\hline $\begin{array}{l}\text { Ratio of book value to } \\
\text { market value of equity }\end{array}$ & BTM $_{\text {it }}$ & -0.215 & -2.380 & 0.018 \\
\hline Determining coefficient & 0.541 & \multicolumn{2}{|c|}{ F statistics } & 15.678 \\
\hline $\begin{array}{l}\text { Adjusted determining } \\
\text { coefficient }\end{array}$ & 0.505 & \multicolumn{2}{|c|}{$\begin{array}{l}\text { Significance of (p-value) } \\
\text { Durbin Watson statistics }\end{array}$} & $\begin{array}{l}.00 \\
1.947\end{array}$ \\
\hline
\end{tabular}

As it is shown in Table 2, determining coefficient is $54.1 \%$ and adjusted determining coefficient is $50.5 \%$. The reason of using adjusted determining coefficient is that, with adding the number of independent variables to regression model, it is possible that the value of $R^{2}$ will be increased. For preventing this and controlling inflation of $\mathrm{R}^{2}, \mathrm{R}^{2}$ adjusted statistics is used which solves the $\mathrm{R}^{2}$ problems. The high value of adjusted determining coefficient $(0.411)$ of fitted regression indicates the high descriptive power of the model.

As per Table 2, the significance level of economic added value variable is equal to 
0.005, which is smaller than the determined significance level in the current study (5\%); on the other hand, the absolute value of $t$ statistics related to this variable $|2 / 843|$ is bigger than the obtained $\mathrm{t}$ statistics from the table with the same freedom degree (1.96). Therefore, this variable is significant in the fitted regression of model (1) and we can use the estimated coefficient for it. The significance level of the variable of company size is equal to 0.009 , which is less than the determined significance level for the current study (5\%); also, the absolute value of the $t$ statistics related to this variable 12.619 is bigger than the obtained t statistics from the table with the same freedom degree (1.96). Also, the variable of the ratio of book value to market value of equity has a smaller significance level comparing to the one determined for this study (0.018 against 0.05 ) and, on the other hand, the absolute value of the $\mathrm{t}$ statistics related to this variable 12.38 is bigger than the obtained $t$ statistics from the table with the same freedom degree (1.96), and therefore this variable is also significant and we can use the estimated coefficient for it.

In general, the results of Table 2 indicate that, at confidence level of $95 \%$, the variables of economic added value and company size have a positive and significant relationship with stock return and the variable of the ratio of book value to market value of equity has a negative and significant relationship with stock return. Therefore, hypothesis 2 of the study indicating a positive and significant relationship between economic added value and stock return is confirmed.

Testing research hypothesis 3

(1) Liquidityit $=1 / 12+0 / 365$ E.V.Ait + 0/248 SIZEit 0/125- BTMit + cit

(2) Rit $=0 / 621+0 / 471$ E.V.Ait $+0 / 367$ SIZEit $-0 / 215 \quad$ BTMit $+\varepsilon i t$

Table 3. Comparison of the Relationship between Economic Added Value with Stock Liquidity and Stock Return

\begin{tabular}{|c|c|c|c|c|c|}
\hline Variable name & $\begin{array}{c}\text { Variable } \\
\text { symbol }\end{array}$ & $\begin{array}{c}\text { Regressio } \\
\text { n model }\end{array}$ & $\begin{array}{c}\text { Variable } \\
\text { coefficient }\end{array}$ & $\stackrel{t}{\text { statisti }}$ & $\begin{array}{c}\text { Significanc } \\
\text { e level }\end{array}$ \\
\hline \multirow{2}{*}{ Constant value } & \multirow{2}{*}{ Constant } & 1 & 1.12 & 5074 & .000 \\
\hline & & 2 & 0.621 & 8.127 & .000 \\
\hline \multirow{2}{*}{$\begin{array}{c}\text { Economic } \\
\text { added value }\end{array}$} & \multirow{2}{*}{ E.V. $A_{\text {it }}$} & 1 & 0.365 & 2.108 & 0.036 \\
\hline & & 2 & 0.471 & 2.843 & 0.005 \\
\hline \multirow{2}{*}{ Company size } & \multirow{2}{*}{$\mathrm{SIZE}_{\mathrm{it}}$} & 1 & 0.248 & 2.871 & 0.004 \\
\hline & & 2 & 0.367 & -2.619 & 0.009 \\
\hline \multirow{2}{*}{$\begin{array}{l}\text { Ratio of book } \\
\text { value to market } \\
\text { value of equity }\end{array}$} & \multirow[b]{2}{*}{ BTM $_{\text {it }}$} & 1 & -0.125 & 2.6327 & 0.0086 \\
\hline & & 2 & -0.215 & -2.380 & 0.018 \\
\hline \multirow{2}{*}{\multicolumn{2}{|c|}{ Determining coefficient }} & 1 & & 0.444 & \\
\hline & & 2 & & 0.541 & \\
\hline \multirow{2}{*}{\multicolumn{2}{|c|}{ Adj. determining coefficient }} & 1 & & 0.411 & \\
\hline & & 2 & & 0.505 & \\
\hline \multicolumn{2}{|c|}{ Wald statistics } & \multicolumn{4}{|c|}{2.126} \\
\hline
\end{tabular}


As it was mentioned in the research method section for studying the significant difference of the relationship between economic added value with stock liquidity (0.365) and stock return (0.471), the Wald test has been used. The mentioned statistics at the confidence level of $95 \%$ is equal to 2.12 and therefore $\mathrm{HO}$ hypothesis indicating non-existence of a significant difference of coefficients at the confidence level of $95 \%$ is rejected and $\mathrm{H} 1$ hypothesis indicating existence of significant difference of the relationship (coefficients) between economic added value with liquidity and stock return is confirmed. Therefore, as it can be seen in the above table, economic added value has a positive and significant relationship with stock liquidity in a way that the coefficient of economic added value in model (1) is equal to 0.365 and descriptive power of the model is $41.1 \%$. On the other hand, economic added value has a positive and significant relationship with stock return in such a way that economic added value in Model (2) is equal to 0.471 and the descriptive power of the model is also $50.5 \%$. Hence this relationship is stronger regarding stock return and therefore main hypothesis is confirmed.

\section{Discussion and Conclusion}

The liquidity topic as a determining factor of stock return was first presented in the beginning of 80s (Chan and Faff, 2003). Liquidity reflects the effect of order flow on price. This effect can be observed in the form of a discount given by a seller or in the form of a reward received by a buyer at the time of ordering in the market. In general, the question that "whether liquidity can affect asset return or not" have not been answered completely and with confidence. Studies show that liquidity factor has effect on asset return and investors have always given attention to it (Omari et al.). The role of liquidity is important in determining assets' price; because investors always give attention to the fact that they want to sell their assets, whether there is a proper market for them or not? As much as the liquidity potential is less for a share, it will have less attraction for investors, unless they would receive more returns from it (Keil Geoffrey et al., 2003). At the macro and national levels, it is expected that as much as the liquidity of a stock is more, it will contain new information for gradual stock changes which leads to increasing the return level (Bortolotti et al., 2006).

Due to the multi-dimensional property of liquidity, reflecting all the properties of it in one single criterion is difficult. In a categorization by Aitken and Comerton Forde, liquidity measurement indicators are divided into two indicators based on orders and trades. The indicators based on trades are more focused on the past rather than advancing forward and, therefore, they necessarily don't indicate the capability of investors for doing fast trades and the related expenses to them. But emergence of electronic trade systems have made possible achievement of more detailed data and, as a result, new liquidity indicators due to the existing orders in the market. These indicators study the capability of doing a trade fast with more accuracy and the expenses related to it. One of the most important criteria are breaking the offered buying and selling prices of the market and the market depth. The most common criteria of liquidity include market width (range), market depth, and market flexibility as well as time (speed of trades).

From macro point of view, existence of liquid capital markets as one of the most effective factors on stock return has so much importance, because liquidity indicates the status of investment 
environment and macroeconomic. Form micro point of view, liquid capital market has the potential of attracting various investors with a variety of trade strategies. Illiquidity of an asset, prevents on time sale of it at the time decline of the price in the whole market (Acharya and Pedersen, 2005).

One of the limitations of this study is regarding the sample selection which includes use of companies with having fiscal year ending of the month of Esfand, no change in fiscal year, necessity of stock trade in the month of Esfand and most important than all the availability of required information for variables. Definitely, using a longer period of time span and more companies will increases the validity and reliability of the study. Another limitation of this study is that the findings of the studies conducted regarding the efficiency of Tehran Stock Exchange don't confirm the market efficiency at a weak level as well (including Sinaei, 1994; and Namazi and Shoshtariyan, 1995) and this will distort the market prices to a great extent. In the current study, for calculation of the ratio of market value to book value and also stock return, we have used stock market value; therefore, lack of efficiency of Tehran Stock Exchange will reduce the possibility of reliance on results in this regard.

\section{References}

Darabi, R., Esfandyari, E., (2009), "relationship between adjusted economic added value, profit prior to tax and interest deduction and cash flow of operational activities with stock market

How to cite this article: Isa Bakhtyari Mansourabad, The Relationship between Economic Value Added with Liquidity and Returns in Companies Listed in Tehran Stock Exchange. International Journal of Advanced Studies in Humanities and Social Science, 2019, 8(2), 126-136. http://www.ijashssjournal.com/article 84351.html value of companies active in food industry listed in Tehran Stock Exchange", Spring Financial Accounting and Auditing Research Center; 1(1): 75-87.

Hassas, Y. Y., Delkhoush, M., (2009), "relationship between economic added value with dividend per share and stock price in companies listed on Stock Exchange", Spring Financial Accounting and Auditing Research Center; 1(1): 1-15.

Mahdavi, G. H., Goyandeh, K., (2009), "relationship between economic added value and refined economic added value with stock return", Summer Financial Accounting and Auditing Research Center; 1(2): 61-86.

Mehrani, S., M., Kaveh, Karami, G., (2004), "using financial and non-financial information for separating successful companies from unsuccessful ones", Journal of Accounting and Auditing, 11th year, issue 38, pp 77-78.

Namazi, M., Heidarpour, F., Mohammadi, K., (2009), "studying the effect of companies shareholders combination (legal and real entities) on trade volume and their stock liquidity", Financial Accounting and Auditing Research of Fall; 1 (3): 1-22.

Yahyazadeh, F., Khoramdin, J., (2008), "role of liquidity factors and illiquidity risk in stock return surplus in Tehran Stock Exchange", Fall Accounting and audit investigations; 15 (53): 101-118. 